\title{
Diagnostic and screening utility of various test methods for malaria - a comparative study of malarial parasites in blood smear, quantitative buffy coat and detection of malarial antigen by immunochromatography and ELISA
}

\author{
A Ashwin*, Febe R Suman, Vinod K Panicker, S Alexander, R Krishnamoorthy \\ From First International Science Symposium on HIV and Infectious Diseases (HIV SCIENCE 2012) \\ Chennai, India. 20-22 January 2012
}

\section{Background}

Malaria causes about 250 million cases of fever and 1 million deaths annually. It is one of the causes of poverty and a major hindrance to economic development. Malaria is caused by protozoa of the genus plasmodium. Early accurate diagnosis is essential to start treatment within 24 hours and to avoid empirical therapy with toxic drugs. This study is aimed at finding out the best diagnostic and screening method for malaria.

\section{Methods}

Blood from 200 clinically suspected malaria patients were subjected to peripheral blood smear examination, quantitative buffy coat, immunochromatography and enzyme linked immunosorbent assay. The sensitivity and specificity were analyzed. The duration, equipment, expertise, electricity and economy needed were considered.

\section{Results}

Peripheral blood smear is highly reliable, species specific, requires expertise and is time consuming. Quantitative buffy coat is a reliable rapid test, but needs economy and experts. Immunochromatography is a rapid, economical, low sensitivity method. Enzyme linked immunosorbant assay is a economical, time consuming, low sensitivity method.

\footnotetext{
* Correspondence: drashwin.anandan@gmail.com

Department of Transfusion Medicine, Sri Ramachandra University, Chennai,
} India

(C) 2012 Ashwin et al; licensee BioMed Central Ltd. This is an Open Access article distributed under the terms of the Creative Commons Attribution License (http://creativecommons.org/licenses/by/2.0), which permits unrestricted use, distribution, and reproduction in any medium, provided the original work is properly cited.

\section{Conclusion}

Peripheral blood smear remains the gold standard technique while quantitative buffy coat is the most suitable rapid test in well equipped laboratories and blood banks with heavy work load. Immunochromatography and enzyme linked immunosorbent assay are suitable for population screening in endemic areas and to monitor anti-malarial treatment.

Published: 4 May 2012

doi:10.1186/1471-2334-12-S1-P81

Cite this article as: Ashwin et al:: Diagnostic and screening utility of various test methods for malaria - a comparative study of malarial parasites in blood smear, quantitative buffy coat and detection of malarial antigen by immunochromatography and ELISA. BMC Infectious Diseases 2012 12(Suppl 1):P81.

Submit your next manuscript to BioMed Central and take full advantage of:

- Convenient online submission

- Thorough peer review

- No space constraints or color figure charges

- Inclusion in PubMed, CAS, Scopus and Google Scholar

- Research which is freely available for redistribution
- Immediate publication on acceptance 